\title{
REVIEW
}

\section{Cognitive and behavioral features of C9FTD/ALS}

\author{
Bradley F Boeve*1 and Neill R Graff-Radford ${ }^{2}$
}

\begin{abstract}
Numerous kindreds with familial frontotemporal dementia or amyotrophic lateral sclerosis or both have been linked to chromosome 9 (C9FTD/ALS), and an expansion of the GGGGCC hexanucleotide repeat in the non-coding region of chromosome 9 open reading frame 72 (C9ORF72) was identified in the summer of 2011 as the pathogenic mechanism. An avalanche of papers on this disorder is in progress, and a relatively distinctive phenotype is taking form. In this review, we present an illustrative case and summarize the demographic, inheritance, clinical, and behavioral aspects and presumed pathologic underpinnings of C9FTD/ALS on the basis of the available data on more than 250 patients with frontotemporal lobar degeneration syndromes, parkinsonism, or ALS or a combination of these disorders.
\end{abstract}

\section{Introduction}

Familial frontotemporal dementia (FTD) with or without parkinsonism has been associated with mutations in genes encoding microtubule-associated protein tau (MAPT), progranulin (PGRN), and less commonly valosin-containing protein $(V C P)$, TAR DNA-binding protein $(T A R D B P)$, and fused in sarcoma (FUS), whereas familial amyotrophic lateral sclerosis (ALS) has been associated with mutations in genes encoding $\mathrm{Cu} / \mathrm{Zn}$ superoxide dismutase-1 (SOD1), TARDBP, and FUS [1-9]. Although the phenotype of familial FTD or ALS linked to chromosome 9 or both has been appreciated for many years [10-17], the pathogenic genetic mutation remained elusive until two teams of investigators discovered the mechanism in the summer of 2011 and published their findings shortly thereafter $[18,19]$. The mutation is an expansion of the GGGGCC hexanucleotide repeat in the non-coding intronic region of the chromosome 9 open reading frame 72 (C9ORF72) gene $[18,19]$, and the disease is known as frontotemporal

*Correspondence: bboeve@mayo.edu

'Department of Neurology, Mayo Clinic, 200 First Street SW, Rochester, MN 55905, USA

Full list of author information is available at the end of the article dementia or amyotrophic lateral sclerosis (or both) linked to chromosome 9 (c9FTD/ALS) [18,20]. A number of papers on C9FTD/ALS have already been published, and a relatively distinctive phenotype is becoming clear. In this review, we present an illustrative case from our index kindred and then summarize the demographic, inheritance, clinical, and behavioral aspects of c9FTD/ALS on the basis of the available data.

\section{Illustrative case from index kindred}

The identification of the mutation in our index kindred known as the Vancouver-San Francisco-Mayo Clinic family 20 reflects collaborative work that was conducted by several groups of investigators over the course of almost two decades [16]. One case we have followed over the course of seven years illustrates many of the core cognitive, behavioral, neuropsychological, and neuroimaging features that cases with c9FTD/ALS frequently exhibit.

A right-handed male began experiencing depression and apathy at age 49 . He is patient III.2 in the report by Boxer and colleagues [16]. His father developed ALS at age 35 and died after a two-and-a-half-year course. His paternal aunt presented with behavioral variant frontotemporal dementia (bvFTD) features at age 46 and shortly thereafter with parkinsonism and ALS and died after a nine-year course. His brother had bvFTD, which was diagnosed at age 49, and parkinsonism, which was diagnosed four years later, and is currently residing in a skilled nursing care facility after a seven-year course. Five other relatives have or had FTD, ALS, or parkinsonism or a combination of these disorders.

The patient presented to our institution at age 53, complaining of severe depression and 'lack of pep'. $\mathrm{He}$ had lost his job because of apathy and poor decisions. He lived in a rural area and remarked that, owing to boredom since he could not find work, a favorite activity was to sit in a lawn chair in his yard with a cooler of beer adjacent to him, hold a rifle in each arm, and 'shoot anything that moves.' The targets included squirrels, birds, and insects. Despite his wife's best efforts to curb this activity and keep him from consuming alcohol, he continued to do so. This eventually led to a drunk driving charge, and as a result, all weapons were removed from his residence. His driver's license was temporarily suspended, yet he was able to evade the local police and drive his own or friends' 
cars, apparently never getting lost or having any accidents. After a six-month period with no driving privileges, he successfully completed a driving safety examination. On one occasion, he picked up a hitchhiker who was seeking shelter, brought him home, but refused to allow the hitchhiker in his home and an altercation ensued.

The patient became increasingly suspicious of his family, neighbors, and local police and health-care providers. Owing to his obstinacy, his wife chose to reside in a separate home and his children chose to no longer interact with him. He remarked that he often heard voices, but other than stating that the Lord was telling him to do good deeds, he would not elaborate on the content of these auditory hallucinations as 'you guys will lock me up and throw away the keys'.

His only source of income was disability benefits. His home was in disarray, and he would drive around town obtaining food from fast-food restaurants, but he managed to live independently. He gained more than 50 pounds since the onset of his symptoms because of hyperphagia and the tendency to consume large quantities of potato chips. His family has worked with the local legal authorities in an attempt to transfer oversight of his medical and financial affairs to his wife, but when he went before a judge, the patient successfully argued that he was competent and absolutely did not want anyone overseeing his affairs.

The longitudinal clinical, behavioral, neuropsychological, and neuroimaging findings in this patient are shown in Figures 1 to 3 . His presenting features were typical of bvFTD, followed shortly thereafter with left hemiparkinsonism that has evolved to an asymmetric akinetic-rigid syndrome without tremor. Asymmetric corticospinal tract signs have also evolved but without features of lower motor neuron dysfunction. His course has been remarkably slowly progressive. As reflected in his neuropsychological performance over time, his episodic memory and visuospatial functions have remained relatively preserved and this likely has allowed him to live independently despite his psychomotor slowing, executive dysfunction, delusions, hallucinations, apathy, and mild parkinsonism.

Neuroimaging findings mirror this remarkably slow clinical progression. Very minimal atrophy has evolved over the course of seven years of serial magnetic resonance imaging (MRI) scans. A flourodeoxyglucose positron emission tomography (FDG-PET) scan image of the brain, performed eight years after the onset of his symptoms, shows relatively mild frontal, parietal, and cingulate cortex hypometabolism.

\section{Literature review}

We reviewed reports with ample numbers of cases having a dementia-predominant phenotype, published through
March 2012. Reports focused on ALS with cognitive and behavioral data were also included. We identified nine recent publications meeting these criteria [20-28], and a summary of the core features associated with c9FTD/ ALS is shown in Table 1.

\section{Cohort characteristics}

More than 250 subjects among more than 230 kindreds with sufficient cognitive/behavioral data are included in these reports to be summarized and reviewed for general consistencies [20-22,24-29]. This accumulation of hundreds of subjects is in itself striking given that these data have been published within seven months since the publication of the landmark papers on the C9ORF72 mutation [18,19]; similar data exist for FTD associated with mutations in the gene encoding $M A P T$ among 134 kindreds since the original report on MAPT mutations in 1996 [1] and in the gene encoding $P G R N$ among 231 kindreds since the original reports on PGRN mutations in 2006 [2,3,30].

Among those series in which the frequency of the C9ORF72 mutation was assessed (some also compared this frequency with the frequency of mutations in $M A P T$ and $P G R N)$, the frequency was calculated as sporadic or familial or both; also, the frequency of FTD \pm parkinsonism \pm ALS was calculated [21,22,24-29]. Most reports state that the C9ORF72 mutation frequency is in the $7 \%$ to $12 \%$ range compared with the $6 \%$ to $10 \%$ range for $M A P T$ and the $4 \%$ to $7 \%$ range for PGRN. These frequencies increase to $13 \%$ to $26 \%$ for C9ORF $72,11 \%$ to $22 \%$ for $M A P T$, and $6 \%$ to $22 \%$ for PGRN when the frequencies of mutations among familial FTD cases are considered. Importantly, despite the recruitment and analyses of familial FTD cases during at least the past 20 years among several teams focused on this issue, the frequency of familial cases without an identified genetic mechanism is in the $45 \%$ to $66 \%$ range, thereby providing ample reasons to continue research in familial FTD.

\section{Demographic characteristics}

The male-to-female ratio on cumulative cases among FTD \pm parkinsonism \pm ALS suggests a slight male predominance $(129: 105$ or $1.23: 1)$. In different series, the mean/ median age of onset is in the 52- to 65-year age range, and the range of age of onset is wide (33 to 78 years). Survival mean/median values are in the 5- to 9-year range, and the range of survival also is wide ( 1 to 22 years). The illustrative case above exemplifies the slow course and long survival of some individuals. In the reports in which this was assessed, those with FTD and concomitant ALS tended to have shorter survival, as one would expect.

\section{Inheritance characteristics}

The disorder of c9FTD/ALS is inherited in an autosomal dominant fashion with high but not complete penetrance, 


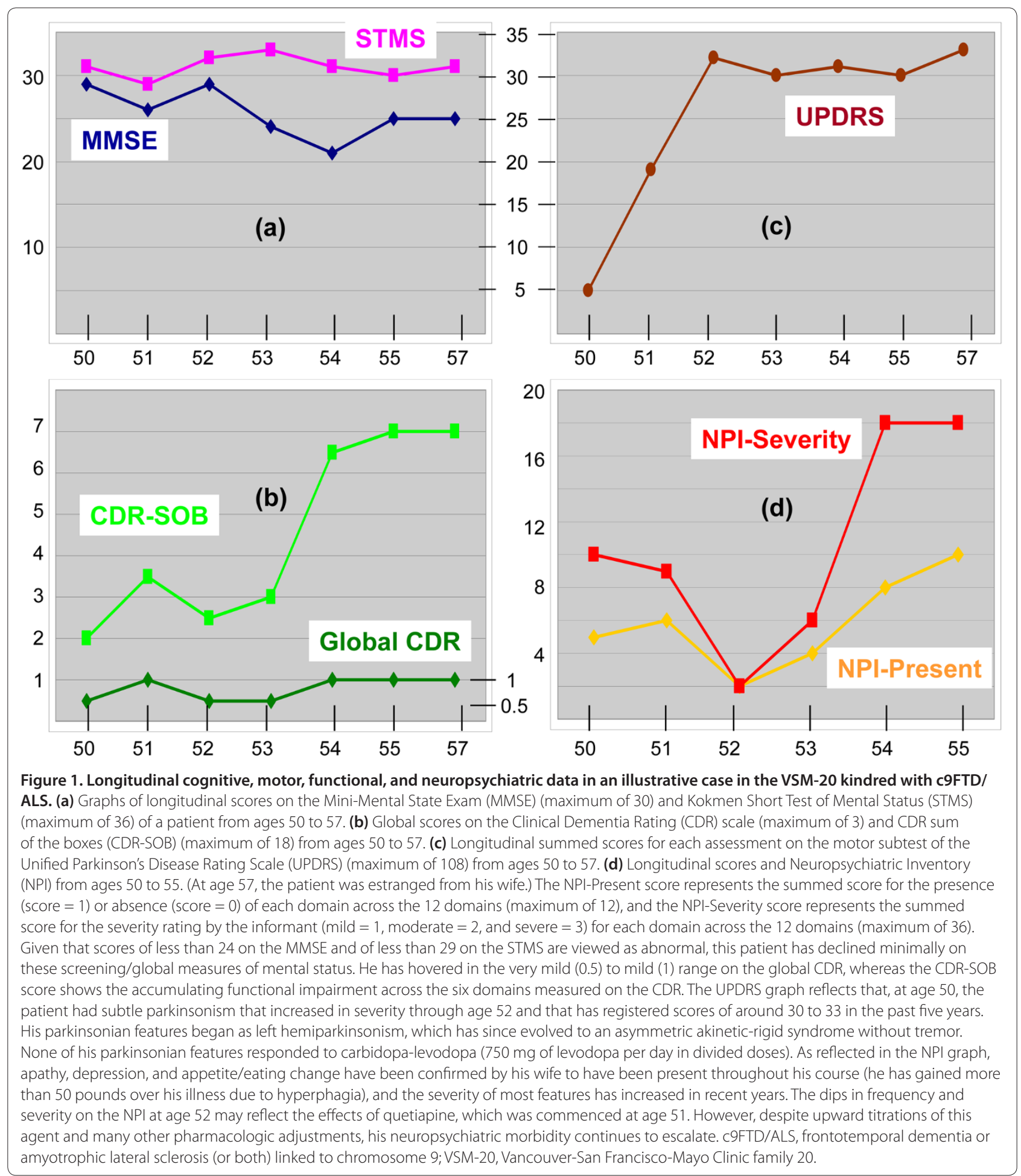

and sporadic cases have been identified in every report published to date. Many reports document families in which succeeding generations appear to have a younger age of onset; hence, these reports suggest genetic anticipation $[21,25,29]$. Given that c9FTD/ALS involves a polynucleotide repeat expansion mechanism, it stands to reason that anticipation could occur. The challenge among geneticists is to resolve the technical aspects of quantifying the number of repeats in this mutation but this has been difficult. One can easily hypothesize that, with increasing numbers of repeats, an earlier age of onset would occur, but this awaits confirmation. 


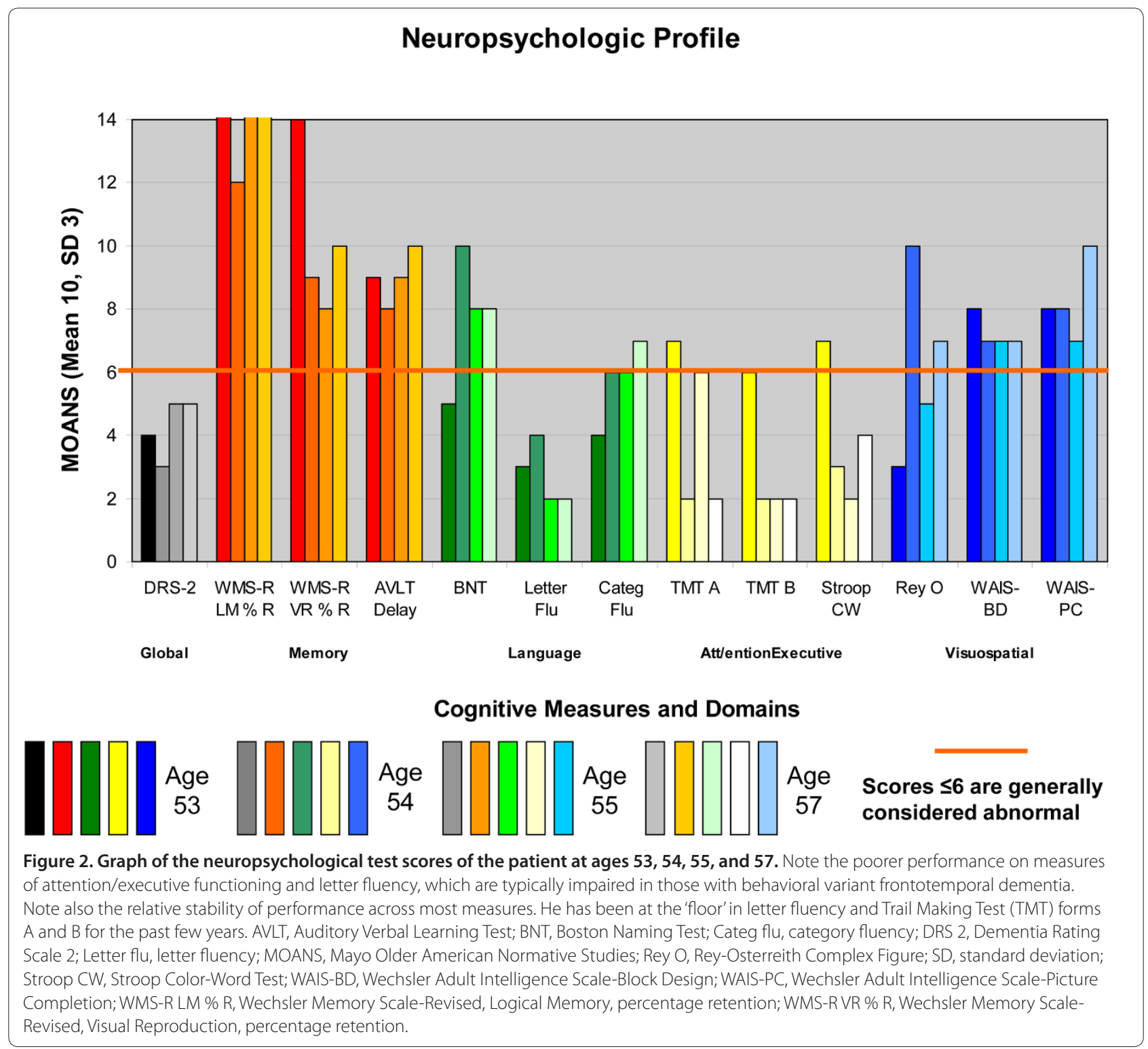

\section{Clinical phenotype}

Clearly, the predominant dementia phenotype is the classic bvFTD syndrome [31,32]. Many have some degree of parkinsonism, which is typically of the akinetic-rigid type without tremor and is levodopa-unresponsive [21]. Others have elements or the full clinical picture of ALS. This phenotype has not yet been reported in C9FTD/ ALS, in contrast to FTD with or without parkinsonism associated with MAPT and PGRN mutations, in which a primary parkinsonian phenotype can occur. Most series do not have any cases with a primary progressive aphasia (PPA) phenotype, although this has been encountered rarely in some series [25-28]. Only one case of the corticobasal syndrome phenotype [33] has been reported in c9FTD/ALS [16]. Though rare, the amnestic presentation diagnosed clinically as probable Alzheimer's disease has been observed across many in the series $[20,21,25,26]$, including one analysis focused on lateonset Alzheimer's disease [34]. The phenotype of dementia with Lewy bodies was reported in a few cases in one series [20]. These observations suggest that the C9ORF72 mutation can manifest as a variety of dementia phenotypes as well as pure ALS, but the vast majority have the core syndrome of bvFTD \pm parkinsonism \pm ALS.

\section{Cognitive features}

The classic bvFTD phenotype involves executive dysfunction and word retrieval difficulties with relative sparing of memory and visuospatial functioning [31,32], as 


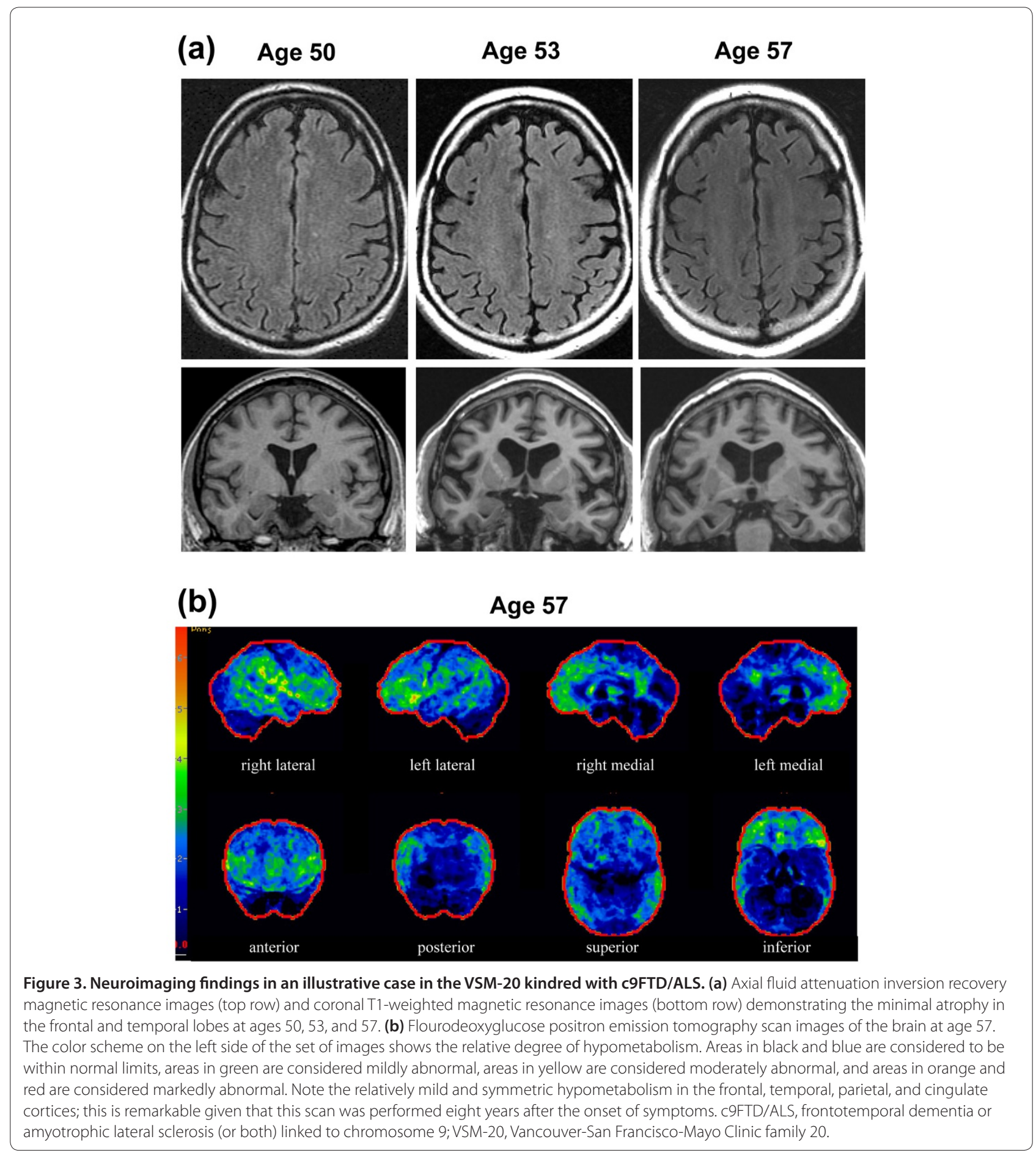

exemplified by our illustrative case. Degeneration of the dorsomedial and dorsolateral cortices and their afferent and efferent connections - two of the critical frontosubcortical neural networks involved in executive functioning, word retrieval, psychomotor speed, motivation, and so on - is the likely substrate underlying the typical bvFTD cognitive features. In some c9FTD/ALS cases, this classic phenotype is not always exhibited, owing mainly to memory being impaired [20,21,25-28]. Visuospatial dysfunction is present in a minority of cases [21,25-28]. In addition to bifrontal and cingulate cortex atrophy, parietal cortex atrophy is part of the signature pattern on MRI [35] and this likely explains visuospatial dysfunction, but memory impairment is harder to explain. 


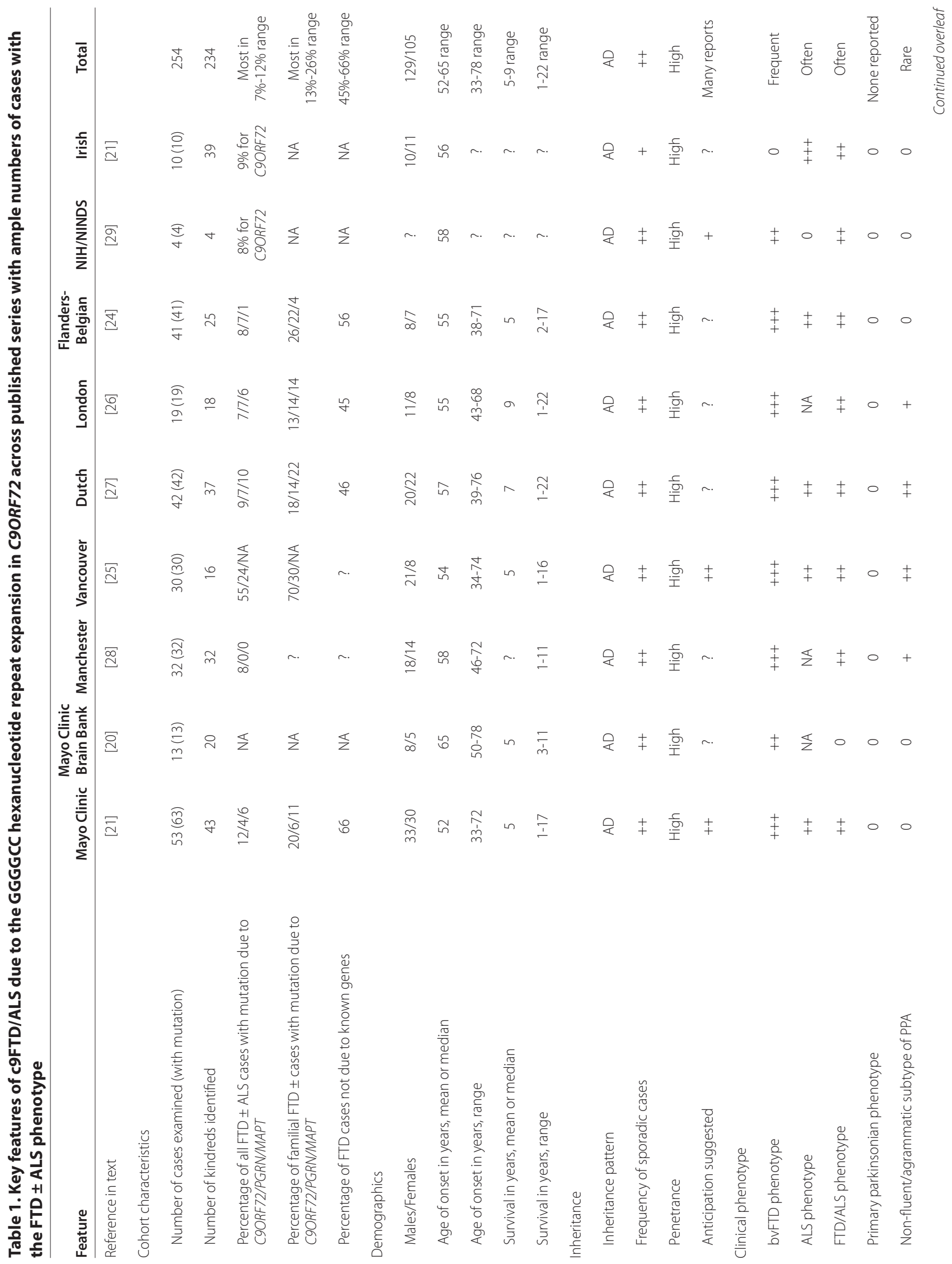




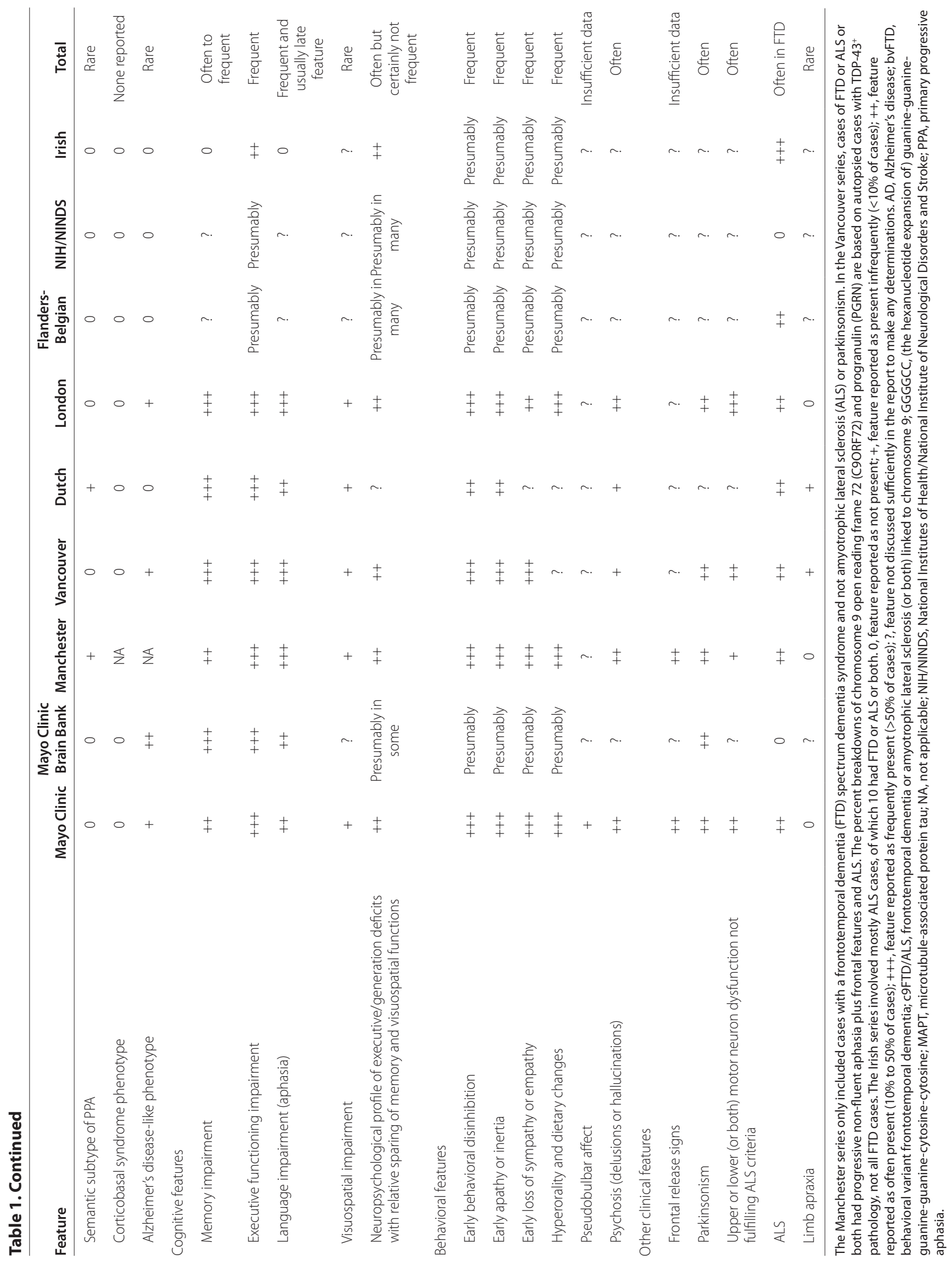


The determination of whether memory is impaired varies on the basis of clinical evaluation, neuropsychological testing, and which tests are used. For example, one can consider the older and more simplistic rubric that memory impairment is due to an encoding versus retrieval deficit. A deficit in encoding implicates the mesial temporal lobe structures with or without other structures in the limbic system such as the medial thalamus, whereas a retrieval deficit implicates the frontosubcortical neural networks. Most cases of c9FTD/ALS have clinical, neuropsychological, and neuroimaging features implicating the frontosubcortical neural networks, and thus a retrieval deficit would be expected, and in one study in which neuropsychological tests were performed in many c9FTD/ALS subjects, performance on delayed recall measures was usually normal [21]. Yet many cases exhibit poor performance on delayed recall measures as well as on recognition of stimuli [26-28], suggesting an encoding deficit, yet the medial temporal lobes tend to be relatively spared, according to neuroimaging studies conducted thus far $[21,26,35]$. However, pathologic studies show that hippocampal sclerosis is frequent and associated with those presenting with an amnestic disorder [20]. This issue is reviewed in more detail in the section on 'Neuropathologic features and their clinical relevance.'

Another challenge is understanding the executive dysfunction in mutation carriers who have the bvFTD phenotype yet no apparent frontotemporal atrophy on MRI or hypometabolism on FDG-PET [21]. The pathologic findings, however, provide evidence that frontal atrophy is indeed more frequent with this phenotype. One hypothesis is that the executive deficits are due, in part, to primary cerebellar dysfunction akin to the cerebellar cognitive affective syndrome [36-38]. All pathologic studies in c9FTD/ALS have shown widespread ubiquitinpositive inclusions in the cerebellum, and this could contribute to 'frontal' dysfunction (see section on 'Neuropathologic features and their clinical relevance'). Furthermore, while neuroimaging studies clearly include the cerebellum as part of the signature pattern of atrophy $[26,35]$, cerebellar degeneration per se tends to be minimal on pathologic analyses, and other clinical features of cerebellar dysfunction, such as limb or truncal ataxia, limb dysmetria, ataxic dysarthria, and nystagmus, have not been appreciated in affected cases. Understanding the mechanism for executive dysfunction in C9FTD/ ALS cases with minimal or no frontotemporal atrophy will require further study.

Language impairment is relatively common in c9FTD/ ALS but is rarely the predominant phenotype; aphasia typically evolves as the illness progresses. When the primary progressive aphasia syndrome is the predominant phenotype, it is typically of the non-fluent/agrammatic type [25-28]. Non-fluent/agrammatic aphasia relates to degeneration of Broca's area or the insula in the dominant hemisphere or both, and in those with a predominant non-fluent/agrammatic PPA phenotype, neuroimaging studies demonstrate this topography of atrophy or hypometabolism [39-44]. However, such PPA phenotype cases in c9FTD/ALS have not been well characterized with detailed speech/language assessments and neuroimaging studies, and so this remains to be seen. Furthermore, symmetric neuroimaging abnormalities are the rule and asymmetric findings are the exception $[21,26,35]$, and so these PPA cases could be the exceptions with focal/asymmetric dominant hemisphere degeneration. One might also predict that if a bilateral and relatively symmetric pattern of degeneration has ensued and if the key anterior language networks are affected, then a non-fluent/agrammatic phenotype could be present. Also, the dominant hemisphere supplementary motor area has recently been implicated in the primary progressive apraxia of speech phenotype $[45,46]$, and this could easily be construed to represent non-fluent aphasia; mesial frontal atrophy/ hypoperfusion/hypometabolism is part of the signature pattern of topography in c9FTD/ALS [21,26,35], and so this mechanism is quite plausible. This is yet another area worthy of further research.

\section{Behavioral features}

The overwhelming majority of cases with a dementia syndrome-predominant phenotype as part of c9FTD/ ALS manifest the full spectrum of the bvFTD features $[31,32]$ : early behavioral disinhibition, early apathy or inertia, early loss of sympathy or empathy, and hyperorality and dietary changes. The dorsolateral prefrontal cortex, orbitofrontal cortex, and anterior cingulate cortex are typically affected, according to neuroimaging and neuropathologic studies $[20,21,26,35]$, and this topography readily explains the full bvFTD spectrum of behavioral features. Yet there are those who do not have neuroimaging evidence of frontal atrophy or hypometabolism [21], and as noted above, perhaps the cerebellar degeneration contributes to these behavioral features similar to the hypothesis that such degeneration might explain executive dysfunction. These 'frontally impaired but frontally normal on neuroimaging' cases clearly deserve ample study, as understanding the neuroanatomic correlates of their impairment will not only aid in understanding the disease of c9FTD/ALS but also enhance our understanding of brain-behavior correlations in general.

A few investigators have observed that some c9FTD/ ALS cases exhibit the most bizarre behavioral manifestations they have ever witnessed among all of the bvFTD patients they have cared for [21,28]. Psychotic features, obsessive-compulsive behaviors, odd ritualistic behaviors, and so on are often striking. A summary of observations by clinicians is presented in Table 2 . 


\section{Table 2. Descriptions of dramatic behavioral manifestations associated with c9FTD/ALS}

Delusions

- $\quad$ The patient believed that others were spying on her and required all blinds to be closed in the home and doors to be locked.

- $\quad$ The patient believed that pieces of plastic were emanating from his head, leading him to pick repetitively at his scalp to remove the'plastic bits' embedded in his skin.

- The patient believed that someone was about to harm her and carried a knife and pistol for self-defense.

- $\quad$ The patient believed he had a weakness of the gluteal muscles and that he therefore had to keep his finger in his anus to prevent incontinence.

- The patient believed that he was under surveillance.

- $\quad$ The patient believed that he was infested by mites, which crawled under his skin and into his extremities. He reported that the mites congregated in his earlobe and that he could reduce their number by pinching his earlobe at regular 10-minute intervals.

- The patient believed that his son was trying to kill him, so the patient barricaded himself in his home.

- The patient believed he was being contacted by letter or phone by dead friends and hatched plans to meet them.

- The patient believed that characters on the television screen were communicating with her.

- The patient believed that someone's wife was trying to harm him and threatened to shoot her.

- The patient believed that people around him and on the television screen were talking about him and calling him names.

Hallucinations

- The patient had visions of the devil.

- The patient heard the voice of God.

- The patient perceived that men, including a man dressed in a gorilla outfit, were hiding in her garden and saw disembodied faces, which she believed to be spirits. As a result, the police were contacted.

Other

- The patient sat in the yard, held rifles in both arms, and 'shot anything that moved' (illustrative case).

- The patient spoke in a high-pitched and child-like voice and behaved as if she was a child.

- The patient underwent a dramatic change in religious beliefs and arranged ritualistic and candle-lit meetings with spirits.

- $\quad$ The patient felt the need to carry a handgun in her purse. When her husband hid the gun, she proceeded to purchase another (and was able to do so without raising the suspicion of the gunshop owner).

- The patient threw lit fireworks though his neighbor's letterbox.

- The patient complained of excessive heat. He threw open doors and windows, refused to allow any heating in the home, and dressed in summer attire in mid-winter. He took to pouring cold water over tepid food to 'cool it down'.

- The patient combed his hair repetitively and vigorously, leading to bleeding of the scalp. The patient wore multiple watches on his arm and donned clothes on the wrong part of his body (for example, trousers on his head and underpants on his arms). He used objects inappropriately (for example, a spoon to clean his teeth and a toilet brush to brush his hair).

- The patient constantly wiped surfaces and washed pots and carried with him a cloth to wipe his shoes before getting into his car and plastic bags to wipe his hands.

- The patient washed his hands, filed his nails, and combed his hair repetitively and drank excessive quantities of water as a remedy for her symptoms, leading to hyponatremia.

- The patient cleaned the house obsessively and followed his dog around, cleaning the surfaces that it had walked on.

Examples were compiled from the clinical series of the authors [21] and that of Snowden and colleagues [28]. c9FTD/ALS, frontotemporal dementia or amyotrophic lateral sclerosis (or both) linked to chromosome 9.

\section{Other clinical features}

Whereas the documentation of other clinical features varied across reports, many cases with frontal release signs, parkinsonism, upper or lower motor neuron dysfunction (or both) not fulfilling criteria for ALS, and the full ALS phenotype were observed. Limb apraxia was rarely documented.

\section{Atypical features}

Atypical features are already emerging. A very interesting (and, for many clinicians, somewhat frightening) finding is the identification of the C9ORF72 mutation in rare cases of the FTD phenocopy syndrome [47]. The FTD phenocopy refers to those individuals who clearly exhibit cognitive and behavioral changes suggestive of bvFTD, but neuropsychological tests and neuroimaging studies tend to be more normal than not during the initial years of symptoms $[48,49]$. The 'typical' FTD phenocopy patient does not show progression on longitudinal clinical, neuropsychological, and neuroimaging evaluations, and such cases are now considered to usually have a non-degenerative substrate for their features. When 
Table 3. Salient features of the FTD-predominant phenotype of c9FTD/ALS due to the GGGGCC hexanucleotide repeat expansion in C9ORF72

Frequency

- The mutation is as frequent as or more frequent than microtubule-associated protein tau (MAPT) or progranulin (PGRM) in most clinical cohorts with FTD \pm parkinsonism $\pm \mathrm{ALS}$.

Demographics

- There is a slight male predominance.

- Age of onset is between 33 and 78, and most patients present in the 40- to 70-year age range.

- Survival is variable but typically is in the 5- to 9-year range.

- Survival is shorter when the ALS phenotype is present.

Inheritance

- Inheritance is autosomal dominant.

- Many examples of incomplete penetrance exist.

- Sporadic cases clearly exist.

- Some kindreds appear to exhibit an anticipation-like phenomenon.

Clinical phenotype

- The characteristic phenotype is bvFTD \pm parkinsonism $\pm A L S$.

- The primary progressive aphasia and Alzheimer's disease-dementia phenotypes are uncommon but do exist.

- The primary parkinsonism and corticobasal syndrome phenotypes are rare to nonexistent.

Cognitive features

- Executive dysfunction is very common, as would be expected in an FTD-spectrum disorder, but the underlying substrate for this cognitive feature is not fully understood in those with no frontotemporal changes on neuroimaging studies.

- Memory impairment is frequent, but the underlying substrate for this is not fully understood.

- Aphasia is frequent but is typically a manifestation as the disease evolves after the predominant bvFTD phenotype. The underlying substrate for aphasia in not fully understood.

- Visuospatial dysfunction in uncommon, but in view of the known parietal atrophy and hypometabolism in such cases, this feature is adequately explained.

- Because memory dysfunction or visuospatial dysfunction or both are present in many cases with c9FTD/ALS, such cases will not fulfill the neuropsychological criterion for bvFTD.

Behavioral features

- Almost all cases with a dementia phenotype have early behavioral disinhibition, early apathy or inertia, early loss of sympathy or empathy, and hyperorality and dietary changes and thus fulfill the bvFTD behavioral criteria.

- Psychosis and other dramatic/bizarre behavior changes can occur.

- The underlying substrate for the bvFTD features in those with minimal or no frontotemporal changes on neuroimaging studies is poorly understood.

Other clinical features

- Many with the bvFTD-predominant phenotype have evidence of parkinsonism or upper or lower motor neuron involvement or a combination of the three.

ALS, amyotrophic lateral sclerosis; bvFTD, behavioral variant frontotemporal dementia; C9FTD/ALS, frontotemporal dementia or amyotrophic lateral sclerosis (or both) linked to chromosome 9; C9ORF72, (gene encoding the mutation in) chromosome 9 open reading frame 72; FTD, frontotemporal dementia; GGGGCC, (the hexanucleotide expansion of) guanine-guanine-guanine-guanine-cytosine-cytosine.

first encountering patients who clearly have bvFTD features but no corroborating evidence of an underlying neurodegenerative disorder, the clinician is faced with the obvious challenge of establishing a confident diagnosis and predicting what the future holds. And since so few cases have come to autopsy, the underlying substrate for their symptoms has not been well characterized. The two cases recently reported with the FTD phenocopy associated with the C9ORF72 mutation are very intriguing [47], not only because such atypical FTD cases do have a neurodegenerative disorder underlying their symptoms but also because of the number of atypical FTD cases who have surely been suspected by seasoned clinicians to have a primary psychiatric disorder. Clinical testing is now commercially available for C9ORF72 mutation detection, and more FTD phenocopy and other atypical neurobehavioral syndromes will undoubtedly be identified with this mutation.

\section{Neuropathologic features and their clinical relevance}

Neuropathologic studies in c9FTD/ALS have shown many consistent findings yet also some unexpected, 


\author{
Table 4. Clues that should alert clinicians to suspect the hexanucleotide repeat expansion in C9ORF72 in individual \\ patients \\ Demographics \\ - Age of onset in the 30- to 70-year age range \\ Inheritance \\ - Apparent autosomal dominant pattern of inheritance of dementia or ALS or both ${ }^{a}$ \\ Clinical phenotype \\ - Presence of the phenotype of bvFTD \pm parkinsonism \pm ALS in the patient and his or her relatives ${ }^{a}$ \\ - Absence of any of the focal/asymmetric focal cortical degenerative syndromes (for example, primary progressive aphasia and corticobasal syndrome) in \\ the patient and his or her relatives ${ }^{a}$ \\ Cognitive/Neuropsychological features \\ - Presence of executive dysfunction and word retrieval deficits ${ }^{\mathrm{a}}$ \\ - The presence of memory impairment or visuospatial impairment or both should not dissuade the suspicion of the mutation if many other clues are \\ present. \\ - Normal or minimally abnormal performance on neuropsychological tests early in the course of behavioral changes should not dissuade the suspicion of \\ the mutation if many other clues are present. \\ Behavioral features \\ - Presence of the 'classic bvFTD features' in the patient, including behavioral disinhibition, early apathy or inertia, early loss of sympathy or empathy, and \\ hyperorality and dietary changes ${ }^{2}$ \\ - Presence of psychosis and other dramatic/bizarre behavior changes in the patient \pm his or her relatives \\ Neuroimaging features \\ - Presence of symmetric bilateral frontal (often mesial more so than dorsolateral) \pm temporal \pm parietal atrophy or hypometabolism \\ - Normal or minimally abnormal neuroimaging findings early in the course of behavioral changes should not dissuade the suspicion of the mutation if many \\ other clues are present. \\ Neuropathologic features \\ - Presence of TDP-43-, ubiquitin-, ubiquilin-, and p62-positive inclusions in the cerebellum in the patient or any of his or her relatives ${ }^{\mathrm{a}}$ \\ This feature is a primary clue for considering the C9ORF72 mutation. ALS, amyotrophic lateral sclerosis; bvFTD, behavioral variant frontotemporal dementia; C9ORF72, \\ (gene encoding the mutation in) chromosome 9 open reading frame 72.
}

variable, and curious findings. All cases studied to date except one (see below) - have had TDP-43 pathology associated with frontal and variable parietal or temporal cortical atrophy (or both) and microscopic evidence of neurodegeneration [20,21,25-28,50-55]. Many have evidence of upper or lower motor neuron degeneration (or both) that may or may not have been appreciated antemortem, but this finding underscores the involvement of the brain and spinal cord motor systems in this disease and also emphasizes the overlapping spectrum of FTD and ALS. Degeneration of the substantia nigra is also common and likely explains the presence of parkinsonism in the significant minority of cases who have parkinsonism. A few cases have had coexisting Alzheimer's disease pathology. One case with an apparent hexanucleotide expansion has been described in association with corticobasal degeneration pathology [28]; hopefully, additional details will be presented in the future to better understand this single case with nonTDP pathology.

Unexpected findings in C9FTD/ALS are the variable histologic features across cases [20,21,25,27,51-53]. Earlier studies suggested that all chromosome 9-linked FTD/
ALS cases had a moderate degree of cortical neurons with neuronal cytoplasmic inclusions and relatively few dystrophic neurites across all cortical layers (which is characteristic of Mackenzie type 3, Sampathu type 2, and harmonized type B FTLD-TDP pathology) [56,57], yet approximately half of c9FTD/ALS cases have had many neurons with neuronal cytoplasmic inclusions and many dystrophic neurites in the cortex, especially in layer 2 (which is characteristic of Mackenzie type 1, Sampathu type 3, and harmonized type A FTLD-TDP pathology and most often associated with mutations in PGRN) $[20,21,57]$. Why this variability exists is not understood, but this finding suggests that there is not a distinctive set of histologic features for c9FTD/ALS based on TDPpositive inclusions alone.

One of the most unexpected and still curious findings in C9FTD/ALS cases is the predominance of ubiquitinpositive inclusions in the cerebellum, which far exceeds the density of TDP-positive inclusions $[20,21,50,51,53,58]$. The ubiquitin-positive inclusions also stain positively for ubiquilin and p62 immunohistochemistry, suggesting a pathophysiological link between C9ORF72 expansions and ubiquilin proteins in ALS and FTLD-TDP 


\section{Table 5. Issues worthy of further study in c9FTD/ALS}

Demographic and inheritance issues

- Is there a slight male predominance in the dementia-predominant phenotype of c9FTD/ALS? If so, why?

- Is the C9ORF72 mutation present across races and continents? If not, does the mutation represent a common founder?

- Why are there such variable ages of onset and durations of disease across affected individuals?

- Does genetic anticipation occur in C9FTD/ALS? If so, does the age of onset decrease as the expansion repeat number increases?

- What explains incomplete penetrance in some families?

- What is the mechanism for explaining sporadic cases?

Clinical phenotype

- Why are the bvFTD or ALS phenotypes or both so consistently expressed?

- Why are the syndromes of primary progressive aphasia, corticobasal syndrome, and primary parkinsonism so uncommon in the C9ORF72 mutation whereas the frequencies of these syndromes are higher in mutations associated with microtubule-associated protein tau (MAPT) and progranulin (PGRN)?

- Does the hexanucleotide repeat length impact the topography of degeneration and therefore the phenotype?

Cognitive features

- What is the underlying substrate for executive dysfunction and word retrieval impairment in those with no frontotemporal changes on neuroimaging studies? Does cerebellar dysfunction contribute to the 'frontal' cognitive features?

- What are the qualitative features of memory impairment on neuropsychological assessment?

- What is the underlying substrate for memory impairment in those with no frontotemporal changes on neuroimaging studies?

- What is the underlying substrate for aphasia, particularly in those with no frontotemporal changes on neuroimaging studies?

- How will c9FTD/ALS cases be viewed for experimental drug trial participation if they do not meet the neuropsychological profile criteria of bvFTD?

Behavioral features

- Why are psychosis and other dramatic/bizarre behavior changes relatively common in c9FTD/ALS? What is the underlying substrate for these behavioral features?

- What is the underlying substrate for the prominent behavioral features in those with minimal or no frontotemporal changes on neuroimaging studies? Does cerebellar dysfunction contribute to these prominent behavioral features?

ALS, amyotrophic lateral sclerosis; bvFTD, behavioral variant frontotemporal dementia; C9FTD/ALS, frontotemporal dementia or amyotrophic lateral sclerosis (or both) linked to chromosome 9; C9ORF72, (gene encoding the mutation in) chromosome 9 open reading frame 72.

$[20,50,51,53,58]$. Yet the degree of neuronal loss in cerebellar structures has been mild to negligible and this may explain why classic cerebellar signs such as ataxia, dysmetria, and nystagmus have not been appreciated or reported. However, the finding of ubiquitin-, ubiquilin-, and p62-positive inclusions in the cerebellum has been present in almost every case in which such immunohistochemistry has been used. Hence, these cerebellar inclusions are now viewed as a highly sensitive and specific marker for the presence of the C9ORF72 mutation.

The cognitive and behavioral features and their known or presumed neuropathologic substrates are described above in the respective sections, but again, the typical cognitive features (executive dysfunction and word retrieval deficits) likely relate to degeneration in the dorsomedial and dorsolateral frontosubcortical networks, and the typical behavioral features (impaired social cognition, prominent apathy, and so on) likely relate to these and other frontosubcortical networks such as the orbitomedial frontal and anterior cingulate circuits. Furthermore, the von Economo neurons in the anterior cingulate and insular regions have been implicated in impaired social cognition [59-61]. These clinical-topography associations are very plausible when abnormalities on MRI, single-photon emission computed tomography, or PET correspond to the specific features that are present in individual cases.

The more challenging circumstance is when obvious cognitive or behavioral changes or both are present and the neuroimaging studies are normal regardless of whether any patient has an obvious neurologic cause or has the less obvious FTD phenocopy syndrome. Memory impairment is not typical of the bvFTD syndrome but is often present in c9FTD/ALS cases; as discussed above, this could relate to hippocampal sclerosis or a retrievalbased deficit due to frontosubcortical dysfunction. Also, even when hippocampal sclerosis is not present, an encoding deficit could relate to dysfunction associated with ubiquitin-, ubiquilin-, and p62-positive inclusions in the hippocampus [53]. Dysfunction associated with these inclusions in the cerebellum as part of the cerebellar cognitive affective syndrome is also possible. This will be challenging to prove or disprove until radioligands that tag these key proteins are available for functional neuroimaging studies [47]. 


\section{Summary}

A summary of the salient features of the FTD-predominant phenotype of c9FTD/ALS due to the GGGGCC hexanucleotide repeat expansion in C9ORF72 is presented in Table 3.

\section{Clues for the clinician to suspect the C9ORF72 mutation}

An important consideration for any clinician evaluating a patient for changes in cognition, behavior, or neuromuscular functioning is when to be suspicious of the mutation in C9ORF72. Clinical clues that should raise suspicion are listed in Table 4.

\section{Future directions}

With any discovery, 'one question answered poses ten new questions' and this is clearly the case in many aspects of c9FTD/ALS. A list of some issues worthy of further study is presented in Table 5. Our hope is that the observations in this review based on what has been published thus far help steer investigators to answer these and other questions associated with this fascinating disorder.

\section{Abbreviations}

ALS, amyotrophic lateral sclerosis; bvFTD, behavioral variant frontotemporal dementia; C9FTD/ALS, frontotemporal dementia or amyotrophic latera sclerosis (or both) linked to chromosome 9; C9ORF72, (gene encoding the mutation in) chromosome 9 open reading frame 72; FDG-PET, flourodeoxyglucose positron emission tomography; FTD, frontotemporal dementia; FTD/ALS, frontotemporal dementia or amyotrophic lateral sclerosis or both; FTLD-MND, frontotemporal lobar degeneration with motor neuron disease; FUS, fused in sarcoma; GGGGCC, (the hexanucleotide expansion of) guanine-guanine-guanine-guanine-cytosine-cytosine; MAPT, microtubuleassociated protein tau; MRI, magnetic resonance imaging; PET, positron emission tomography; PGRN, progranulin; PPA, primary progressive aphasia; TARDBP, TAR DNA-binding protein.
\end{abstract}

\section{Competing interests}

This paper was supported by P50 AG016574. Ronald C Petersen is the principal investigator. BFB declares that he has no competing interests. He has served as an investigator for clinical trials sponsored by Cephalon, Inc. (Frazer, PA, USA), Allon Pharmaceuticals Inc. (Vancouver, BC, Canada), and GE Healthcare (Little Chalfont, Buckinghamshire, UK). He receives royalties from the publication of a book entitled the Behavioral Neurology of Dementia (Cambridge: Cambridge University Press; 2009). He has received honoraria from the American Academy of Neurology. NRG-R declares that he has no competing interests. He is on the scientific advisory board of Codman (part of DePuy Orthopaedics, Inc, Warsaw, IN, USA) and is chair of the data and safety monitoring board of Baxter (Deerfield, IL, USA) regarding an IGIV (immune globulin administered intravenously) trial in Alzheimer's disease, an editor for the Neurologist, and part of multicenter trials for Allon Pharmaceuticals Inc. (progressive supranuclear palsy), Janssen (Titusville, NJ, USA), Pfizer Inc (New York, NY, USA) (bapineuzumab for Alzheimer's disease), and Forest Laboratories, Inc. (New York, NY, USA) using memantine in frontotemporal dementia.

\section{Authors' contributions}

Both authors contributed to the analysis and views expressed in this review. BFB drafted the manuscript, and NRG-R revised it critically. Both authors read and approved the final manuscript.

\section{Acknowledgments}

This work was supported by the 'Mayo Alzheimer's Disease Research Center' (P50 AG016574), the 'Mayo Alzheimer's Disease Patient Registry' (UO1 AG006786), 'Identifying Mechanisms of Dementia: Role for MRI in the Era of Molecular Imaging' (RO1 AG011378), and the Robert H. and Clarice Smith and Abigail Van Buren Alzheimer's Disease Research Program of the Mayo Foundation. We thank our many collaborators across the Mayo Clinic sites in Rochester, MN; Jacksonville, FL; and Scottsdale, AZ. We thank lan Mackenzie, Adam Boxer, and Bruce Miller for collaborating on the VSM-20 (Vancouver-San Francisco-Mayo Clinic family 20) kindred. We particularly thank the patients and their families for participating in aging and neurodegenerative disease research.

\section{Author details}

'Department of Neurology, Mayo Clinic, 200 First Street SW, Rochester, MN 55905, USA. '2Department of Neurology, Mayo Clinic, 4500 San Pablo Road, Jacksonville, FL 32224, USA

Published: 20 July 2012

\section{References}

1. Hutton M, Lendon CL, Rizzu P, Baker M, Froelich S, Houlden H, PickeringBrown S, Chakraverty S, Isaacs A, Grover A, Hackett J, Adamson J, Lincoln S, Dickson D, Davies P, Petersen RC, Stevens M, de Graaff E, Wauters E, van Baren J, Hillebrand M, Joosse M, Kwon JM, Nowotny P, Che LK, Norton J, Morris JC, Reed LA, Trojanowski J, Basun H, et al.: Association of missense and 5'-splicesite mutations in tau with the inherited dementia FTDP-17. Nature 1998, 393:702-705.

2. Baker M, Mackenzie IR, Pickering-Brown SM, Gass J, Rademakers R, Lindholm C, Snowden J, Adamson J, Sadovnick AD, Rollinson S, Cannon A, Dwosh E, Neary D, Melquist S, Richardson A, Dickson D, Berger Z, Eriksen J, Robinson T, Zehr C, Dickey CA, Crook R, McGowan E, Mann D, Boeve B, Feldman H, Hutton M: Mutations in progranulin cause tau-negative frontotemporal dementia linked to chromosome 17. Nature 2006, 442:916-919.

3. Cruts M, Gijselinck I, van der Zee J, Engelborghs S, Wils H, Pirici D, Rademakers R, Vandenberghe R, Dermaut B, Martin JJ, van Duijn C, Peeters K, Sciot R, Santens P, De Pooter T, Mattheijssens M, Van den Broeck M, Cuijt I, Vennekens K, De Deyn PP, Kumar-Singh S, Van Broeckhoven C: Null mutations in progranulin cause ubiquitin positive frontotemporal dementia linked to chromosome 17q21. Nature 2006, 442:920-924.

4. Watts G, Wymer J, Kovach M, Mehta S, Mumm S, Darvish D, Pestronk A, Whyte M, Kimonis V: Inclusion body myopathy associated with Paget disease of bone and frontotemporal dementia is caused by mutant valosincontaining protein. Nat Genet 2004, 36:377-381.

5. Sreedharan J, Blair IP, Tripathi VB, Hu X, Vance C, Rogelj B, Ackerley S, Durnall JC, Williams KL, Buratti E, Baralle F, de Belleroche J, Mitchell JD, Leigh PN, Al-Chalabi A, Miller CC, Nicholson G, Shaw CE: TDP-43 mutations in familial and sporadic amyotrophic lateral sclerosis. Science 2008, 319:1668-1672.

6. Kabashi E, Valdmanis PN, Dion P, Spiegelman D, McConkey BJ, Vande Velde C, Bouchard JP, Lacomblez L, Pochigaeva K, Salachas F, Pradat PF, Camu W, Meininger $V$, Dupre N, Rouleau GA: TARDBP mutations in individuals with sporadic and familial amyotrophic lateral sclerosis. Nat Genet 2008, 40:572-574.

7. Kwiatkowski TJ Jr., Bosco DA, Leclerc AL, Tamrazian E, Vanderburg CR, Russ C, Davis A, Gilchrist J, Kasarskis EJ, Munsat T, Valdmanis P, Rouleau GA, Hosler BA Cortelli P, de Jong PJ, Yoshinaga Y, Haines JL, Pericak-Vance MA, Yan J, Ticozzi N, Siddique T, McKenna-Yasek D, Sapp PC, Horvitz HR, Landers JE, Brown RH Jr:: Mutations in the FUS/TLS gene on chromosome 16 cause familial amyotrophic lateral sclerosis. Science 2009, 323:1205-1208.

8. Vance C, Rogelj B, Hortobágyi T, De Vos KJ, Nishimura AL, Sreedharan J, Hu X, Smith B, Ruddy D, Wright P, Ganesalingam J, Williams KL, Tripathi V, Al-Saraj S, Al-Chalabi A, Leigh PN, Blair IP, Nicholson G, de Belleroche J, Gallo JM, Miller CC, Shaw CE: Mutations in FUS, an RNA processing protein, cause familial amyotrophic lateral sclerosis type 6. Science 2009, 323:1208-1211.

9. Rosen DR, Siddique T, Patterson D, Figlewicz DA, Sapp P, Hentati A, Donaldson D, Goto J, O'Regan JP, Deng HX, Rahmani Z, Krizus A, McKenna-Yasek D, Cayabyab A, Gaston SM, Berger R, Tanzi RE, Halperin JJ, Herzfeldt B, Van den Bergh R, Hung WY, Bird T, Deng G, Mulder DW, Smyth C, Laing NG, Soriano E, Pericak-Vance MA, HainesJ, RouleauGA, et al:: Mutations in $\mathrm{Cu} / \mathrm{Zn}$ superoxide dismutase gene are associated with familial amyotrophic lateral sclerosis. Nature 1993, 362:59-62. 
10. Morita M, Al-Chalabi A, Andersen PM, Hosler B, Sapp P, Englund E, Mitchell JE, Habgood JJ, de Belleroche J, Xi J, Jongjaroenprasert W, Horvitz HR, Gunnarsson LG, Brown RH Jr: A locus on chromosome 9p confers susceptibility to ALS and frontotemporal dementia. Neurology 2006, 66:839-844.

11. Vance C, Al-Chalabi A, Ruddy D, Smith BN, Hu X, Sreedharan J, Siddique T, Schelhaas HJ, Kusters B, Troost D, Baas F, de Jong V, Shaw CE: Familial amyotrophic lateral sclerosis with frontotemporal dementia is linked to a locus on chromosome 9p13.2-21.3. Brain 2006, 129:868-876.

12. Valdmanis P, Dupre N, Bouchard J, Camu W, Salachas F, Meininger V, Strong M, Rouleau G: Three families with amyotrophic lateral sclerosis and frontotemporal dementia with evidence of linkage to chromosome $9 p$. Arch Neurol 2007, 64:240-245.

13. Luty AA, Kwok JB, Thompson EM, Blumbergs P, Brooks WS, Loy CT, DobsonStone C, Panegyres PK, Hecker J, Nicholson GA, Halliday GM, Schofield PR: Pedigree with frontotemporal lobar degeneration--motor neuron disease and Tar DNA binding protein-43 positive neuropathology: genetic linkage to chromosome 9. BMC Neurol 2008, 8:32.

14. Le Ber I, Camuzat A, Berger E, Hannequin D, Laquerrière A, Golfier V, Seilhean D. Viennet G, Couratier P, Verpillat P, Heath S, Camu W, Martinaud O, Lacomblez L, Vercelletto M, Salachas F, Sellal F, Didic M, Thomas-Anterion C, Puel M, Michel BF, Besse C, Duyckaerts C, Meininger V, Campion D, Dubois B, Brice A; French Research Network on FTD/FTD-MND: Chromosome 9plinked families with frontotemporal dementia associated with motor neuron disease. Neurology 2009, 72:1669-1676.

15. Gijselinck I, Engelborghs S, Maes G, Cuijt I, Peeters K, Mattheijssens M, Joris G, Cras P, Martin JJ, De Deyn PP, Kumar-Singh S, Van Broeckhoven C, Cruts M: Identification of 2 Loci at chromosomes 9 and 14 in a multiplex family with frontotemporal lobar degeneration and amyotrophic lateral sclerosis. Arch Neurol 2010, 67:606-616.

16. Boxer AL, Mackenzie IR, Boeve BF, Baker M, Seeley WW, Crook R, Feldman H, Hsiung GY, Rutherford N, Laluz V, Whitwell J, Foti D, McDade E, Molano J, Karydas A, Wojtas A, Goldman J, Mirsky J, Sengdy P, Dearmond S, Miller BL, Rademakers R: Clinical, neuroimaging and neuropathological features of a new chromosome 9p-linked FTD-ALS family. J Neurol Neurosurg Psychiatry 2011, 82:196-203.

17. Pearson JP, Williams NM, Majounie E, Waite A, Stott J, Newsway V, Murray A, Hernandez D, Guerreiro R, Singleton AB, Neal J, Morris HR: Familial frontotemporal dementia with amyotrophic lateral sclerosis and a shared haplotype on chromosome 9p. J Neuro/ 2011, 258:647-655.

18. DeJesus-Hernandez M, Mackenzie IR, Boeve BF, Boxer AL, Baker M, Rutherford NJ, Nicholson AM, Finch NA, Flynn H, Adamson J, Kouri N, Wojtas A, Sengdy P, Hsiung GY, Karydas A, Seeley WW, Josephs KA, Coppola G, Geschwind DH, Wszolek ZK, Feldman H, Knopman DS, Petersen RC, Miller BL, Dickson DW Boylan KB, Graff-Radford NR, Rademakers R: Expanded GGGGCC hexanucleotide repeat in noncoding region of C9ORF72 causes chromosome 9p-linked FTD and ALS. Neuron 2011, 72:245-256.

19. Renton AE, Majounie E, Waite A, Simón-Sánchez J, Rollinson S, Gibbs JR, Schymick JC, Laaksovirta H, van Swieten JC, Myllykangas L, Kalimo H, Paetau A, Abramzon Y, Remes AM, Kaganovich A, Scholz SW, Duckworth J, Ding J, Harmer DW, Hernandez DG, Johnson JO, Mok K, Ryten M, Trabzuni D, Guerreiro RJ, Orrell RW, Neal J, Murray A, Pearson J, Jansen IE, et al:: A hexanucleotide repeat expansion in C9ORF72 is the cause of chromosome 9p21-linked ALS-FTD. Neuron 2011, 72:257-268.

20. Murray ME, DeJesus-Hernandez M, Rutherford NJ, Baker M, Duara R, GraffRadford NR, Wszolek ZK, Ferman TJ, Josephs KA, Boylan KB, Rademakers R, Dickson DW: Clinical and neuropathologic heterogeneity of c9FTD/ALS associated with hexanucleotide repeat expansion in C9ORF72. Acta Neuropathol 2011, 122:673-690.

21. Boeve BF, Boylan KB, Graff-Radford NR, DeJesus-Hernandez M, Knopman DS, Pedraza O, Vemuri P, Jones D, Lowe V, Murray ME, Dickson DW, Josephs KA, Rush BK, Machulda MM, Fields JA, Ferman TJ, Baker M, Rutherford NJ, Adamson J, Wszolek ZK, Adeli A, Savica R, Boot B, Kuntz KM, Gavrilova R, Reeves A, Whitwell J, Kantarci K, Jack CR Jr., Parisi JE, et al: Characterization of frontotemporal dementia and/or amyotrophic lateral sclerosis associated with the GGGGCC repeat expansion in C9ORF72. Brain 2012, 135:765-783.

22. Byrne S, Elamin M, Bede P, Shatunov A, Walsh C, Corr B, Heverin M, Jordan N, Kenna K, Lynch C, McLaughlin RL, Iyer PM, O'Brien C, Phukan J, Wynne B, Bokde AL, Bradley DG, Pender N, Al-Chalabi A, Hardiman O: Cognitive and clinical characteristics of patients with amyotrophic lateral sclerosis carrying a C9orf72 repeat expansion: a population-based cohort study.
Lancet Neurol 2012, 11:232-240.

23. Chiò A, Borghero G, Restagno G, Mora G, Drepper C, Traynor BJ, Sendtner M, Brunetti M, Ossola I, Calvo A, Pugliatti M, Sotgiu MA, Murru MR, Marrosu MG, Marrosu F, Marinou K, Mandrioli J, Sola P, Caponnetto C, Mancardi G, Mandich P, La Bella V, Spataro R, Conte A, Monsurrò MR, Tedeschi G, Pisano F, Bartolomei I, Salvi F, Lauria Pinter G, et al.: Clinical characteristics of patients with familial amyotrophic lateral sclerosis carrying the pathogenic GGGGCC hexanucleotide repeat expansion of C9ORF72. Brain 2012, 135:784-793.

24. Gijselinck I, Van Langenhove T, van der Zee J, Sleegers K, Philtjens S, Kleinberger G, Janssens J, Bettens K, Van Cauwenberghe C, Pereson S, Engelborghs S, Sieben A, De Jonghe P, Vandenberghe R, Santens P, De Bleecker J, Maes G, Bäumer V, Dillen L, Joris G, Cuijt I, Corsmit E, Elinck E, Van Dongen J, Vermeulen S, Van den Broeck M, Vaerenberg C, Mattheijssens M, Peeters K, Robberecht W, et al.: A C9orf72 promoter repeat expansion in a Flanders-Belgian cohort with disorders of the frontotemporal lobar degeneration-amyotrophic lateral sclerosis spectrum: a gene identification study. Lancet Neurol 2012, 11:54-65.

25. Hsiung GY, DeJesus-Hernandez M, Feldman HH, Sengdy P, Bouchard-Kerr P Dwosh E, Butler R, Leung B, Fok A, Rutherford NJ, Baker M, Rademakers R, Mackenzie IR: Clinical and pathological features of familial frontotemporal dementia caused by C9ORF72 mutation on chromosome 9p. Brain 2012, 135:709-722.

26. Mahoney CJ, Beck J, Rohrer JD, Lashley T, Mok K, Shakespeare T, Yeatman T, Warrington EK, Schott JM, Fox NC, Rossor MN, Hardy J, Collinge J, Revesz T, Mead S, Warren JD: Frontotemporal dementia with the C9ORF72 hexanucleotide repeat expansion: clinical, neuroanatomical and neuropathological features. Brain 2012, 135:736-750.

27. Simón-Sánchez J, Dopper EG, Cohn-Hokke PE, Hukema RK, Nicolaou N, Seelaar H, de Graaf JR, de Koning I, van Schoor NM, Deeg DJ, Smits M, Raaphorst J, van den Berg LH, Schelhaas HJ, De Die-Smulders CE, MajoorKrakauer D, Rozemuller AJ, Willemsen R, Pijnenburg YA, Heutink P, van Swieten JC: The clinical and pathological phenotype of C9ORF72 hexanucleotide repeat expansions. Brain 2012, 135:723-735

28. Snowden JS, Rollinson S, Thompson JC, Harris JM, Stopford CL, Richardson AM, Jones M, Gerhard A, Davidson YS, Robinson A, Gibbons L, Hu Q, DuPlessis D, Neary D, Mann DM, Pickering-Brown SM: Distinct clinical and pathological characteristics of frontotemporal dementia associated with C9ORF72 mutations. Brain 2012, 135:693-708

29. Ferrari R, Mok K, Moreno JH, Cosentino S, Goldman J, Pietrini P, Mayeux R, Tierney MC, Kapogiannis D, Jicha GA, Murrell JR, Ghetti B, Wassermann EM, Grafman J, Hardy J, Huey ED, Momeni P: Screening for C9ORF72 repeat expansion in FTLD. Neurobiol Aging 2012, 33:1850.e1-1850.e11.

30. Alzheimer Disease \& Frontotemporal Dementia Mutation Database [http://www.molgen.ua.ac.be/Admutations/].

31. Neary D, Snowden JS, Gustafson L, Passant U, Stuss D, Black S, Freedman M Kertesz A, Robert PH, Albert M, Boone K, Miller BL, Cummings J, Benson DF Frontotemporal lobar degeneration: a consensus on clinical diagnostic criteria. Neurology 1998, 51:1546-1554.

32. Rascovsky K, Hodges JR, Knopman D, Mendez MF, Kramer JH, Neuhaus J, van Swieten JC, Seelaar H, Dopper EG, Onyike CU, Hillis AE, Josephs KA, Boeve BF, Kertesz A, Seeley WW, Rankin KP, Johnson JK, Gorno-Tempini ML, Rosen H, Prioleau-Latham CE, Lee A, Kipps CM, Lillo P, Piquet O, Rohrer JD, Rossor MN, Warren JD, Fox NC, Galasko D, Salmon DP, et al:. Sensitivity of revised diagnostic criteria for the behavioural variant of frontotemporal dementia. Brain 2011, 134:2456-2477.

33. Boeve B, Lang A, Litvan I: Corticobasal degeneration and its relationship to progressive supranuclear palsy and frontotemporal dementia. Ann Neurol 2003, 54:S15-519.

34. Majounie E, Abramzon $Y$, Renton AE, Perry R, Bassett SS, Pletnikova O, Troncoso JC, Hardy J, Singleton AB, Traynor BJ: Repeat expansion in C9ORF72 in Alzheimer's disease. N Engl J Med 2012, 366:283-284.

35. Whitwell JL, Weigand SD, Boeve BF, Senjem ML, Gunter JL, DeJesusHernandez M, Rutherford NJ, Baker M, Knopman DS, Wszolek ZK, Parisi JE, Dickson DW, Petersen RC, Rademakers R, Jack CR Jr., Josephs KA: Neuroimaging signatures of frontotemporal dementia genetics: C9ORF72, tau, progranulin and sporadics. Brain 2012, 135:794-806

36. Schmahmann JD, Sherman JC: The cerebellar cognitive affective syndrome. Brain 1998, 121 (Pt 4):561-579.

37. Schmahmann JD, Weilburg JB, Sherman JC: The neuropsychiatry of the cerebellum - insights from the clinic. Cerebellum 2007, 6:254-267. 
38. Schmahmann JD: The role of the cerebellum in cognition and emotion: personal reflections since 1982 on the dysmetria of thought hypothesis, and its historical evolution from theory to therapy. Neuropsychol Rev 2010 20:236-260.

39. Josephs KA, Duffy JR, Strand EA, Whitwell JL, Layton KF, Parisi JE, Hauser MF, Witte RJ, Boeve BF, Knopman DS, Dickson DW, Jack CR Jr., Petersen RC: Clinicopathological and imaging correlates of progressive aphasia and apraxia of speech. Brain 2006, 129:1385-1398.

40. Josephs KA, Whitwell JL, Duffy JR, Vanvoorst WA, Strand EA, Hu WT, Boeve BF, Graff-Radford NR, Parisi JE, Knopman DS, Dickson DW, Jack CR Jr., Petersen RC: Progressive aphasia secondary to Alzheimer disease vs FTLD pathology. Neurology 2008, 70:25-34

41. Gorno-Tempini M, Dronkers N, Rankin K, Ogar J, Phengrasamy L, Rosen H, Johnson J, Weiner M, Miller B: Cognition and anatomy in three variants of primary progressive aphasia. Ann Neurol 2004, 55:335-346.

42. Gorno-Tempini ML, Hillis AE, Weintraub S, Kertesz A, Mendez M, Cappa SF, Ogar JM, Rohrer JD, Black S, Boeve BF, Manes F, Dronkers NF, Vandenberghe R, Rascovsky K, Patterson K, Miller BL, Knopman DS, Hodges JR, Mesulam MM, Grossman M: Classification of primary progressive aphasia and its variants. Neurology 2011, 76:1006-1014

43. Bonner MF, Ash S, Grossman M: The new classification of primary progressive aphasia into semantic, logopenic, or nonfluent/agrammatic variants. Curr Neurol Neurosci Rep 2010, 10:484-490.

44. Grossman M: Primary progressive aphasia: clinicopathological correlations. Nat Rev Neurol 2010, 6:88-97.

45. Josephs KA, Duffy JR, Fossett TR, Strand EA, Claassen DO, Whitwell JL, Peller PJ: Fluorodeoxyglucose $\mathrm{F} 18$ positron emission tomography in progressive apraxia of speech and primary progressive aphasia variants. Arch Neurol 2010, 67:596-605

46. Josephs KA, Duffy JR, Strand EA, Machulda MM, Senjem ML, Master AV, Lowe VJ, Jack CR Jr., Whitwell JL: Characterizing a neurodegenerative syndrome: primary progressive apraxia of speech. Brain 2012 Mar 1. [Epub ahead of print].

47. Khan BK, Yokoyama JS, Takada LT, Sha SJ, Rutherford NJ, Fong JC, Karydas AM, Wu T, Ketelle RS, Baker MC, Hernandez MD, Coppola G, Geschwind DH, Rademakers R, Lee SE, Rosen HJ, Rabinovici GD, Seeley WW, Rankin KP, Boxer AL, Miller BL: Atypical, slowly progressive behavioural variant frontotemporal dementia associated with C9ORF72 hexanucleotide expansion. J Neurol Neurosurg Psychiatry 2012, 83:358-364.

48. Kipps CM, Nestor PJ, Fryer TD, Hodges JR: Behavioural variant frontotemporal dementia: not all it seems? Neurocase 2007, 13:237-247.

49. Kipps CM, Hodges JR, Fryer TD, Nestor PJ: Combined magnetic resonance imaging and positron emission tomography brain imaging in behavioural variant frontotemporal degeneration: refining the clinical phenotype. Brain 2009, 132:2566-2578

50. Al-Sarraj S, King A, Troakes C, Smith B, Maekawa S, Bodi I, Rogelj B, Al-Chalabi A, Hortobagyi T, Shaw CE: p62 positive, TDP-43 negative, neuronal cytoplasmic and intranuclear inclusions in the cerebellum and hippocampus define the pathology of C9orf72-linked FTLD and MND/
ALS. Acta Neuropathol 2011, 122:691-702.

51. Brettschneider J, Van Deerlin VM, Robinson JL, Kwong L, Lee EB, Ali YO, Safren N, Monteiro MJ, Toledo JB, Elman L, McCluskey L, Irwin DJ, Grossman M, Molina-Porcel L, Lee VM, Trojanowski JQ: Pattern of ubiquilin pathology in ALS and FTLD indicates presence of C9ORF72 hexanucleotide expansion. Acta Neuropathol 2012, 123:825-839.

52. Cooper-Knock J, Hewitt C, Highley JR, Brockington A, Milano A, Man S, Martindale J, Hartley J, Walsh T, Gelsthorpe C, Baxter L, Forster G, Fox M, Bury J, Mok K, McDermott CJ, Traynor BJ, Kirby J, Wharton SB, Ince PG, Hardy J, Shaw PJ: Clinico-pathological features in amyotrophic lateral sclerosis with expansions in C9ORF72. Brain 2012, 135:751-764

53. Stewart H, Rutherford NJ, Briemberg H, Krieger C, Cashman N, Fabros M, Baker M, Fok A, DeJesus-Hernandez M, Eisen A, Rademakers R, Mackenzie IR: Clinical and pathological features of amyotrophic lateral sclerosis caused by mutation in the C9ORF72 gene on chromosome 9p. Acta Neuropathol 2012, 123:409-417

54. Troakes C, Maekawa S, Wijesekera L, Rogelj B, Siklós L, Bell C, Smith B, Newhouse S, Vance C, Johnson L, Hortobágyi T, Shatunov A, Al-Chalabi A, Leigh N, Shaw CE, King A, Al-Sarraj S: An MND/ALS phenotype associated with C9orf72 repeat expansion: Abundant p62-positive, TDP-43-negative inclusions in cerebral cortex, hippocampus and cerebellum but without associated cognitive decline. Neuropathology 2011 Dec 19. [Epub ahead of print]

55. van Langenhove T, van der Zee J, van Broeckhoven C: The molecular basis of the frontotemporal lobar degeneration-amyotrophic lateral sclerosis spectrum. Ann Med 2012 Mar 16. [Epub ahead of print].

56. Mackenzie IR: The neuropathology of FTD associated With ALS. Alzheimer Dis Assoc Disord 2007, 21:S44-49.

57. Mackenzie I, Neumann M, Baborie A, Sampathu D, Du Plessis D, Jaros E, Perry R, Trojanowski J, Mann D, Lee V: A harmonized classification system for FTLD-TDP pathology. Acta Neuropathol 2011, 122:111-113.

58. Lin W, Dickson DW: Ultrastructure of ubiquitin-positive, TDP-43-negative neuronal inclusions in cerebral cortex of C9ORF72-linked frontotemporal lobar degeneration/amyotrophic lateral sclerosis. Neuropathology 2012 March 7 [Epub ahead of print].

59. Seeley WW, Carlin DA, Allman JM, Macedo MN, Bush C, Miller BL, Dearmond SJ: Early frontotemporal dementia targets neurons unique to apes and humans. Ann Neurol 2006, 60:660-667.

60. Seeley WW: Selective functional, regional, and neuronal vulnerability in frontotemporal dementia. Curr Opin Neurol 2008, 21:701-707.

61. Kim EJ, Sidhu M, Gaus SE, Huang EJ, Hof PR, Miller BL, DeArmond SJ, Seeley WW: Selective frontoinsular von Economo neuron and fork cell loss in early behavioral variant frontotemporal dementia. Cereb Cortex 2012, 22:251-259.

doi:10.1186/alzrt132

Cite this article as: Boeve BF, Graff-Radford NR: Cognitive and behavioral features of C9FTD/ALS. Alzheimer's Research \& Therapy 2012, 4:29. 